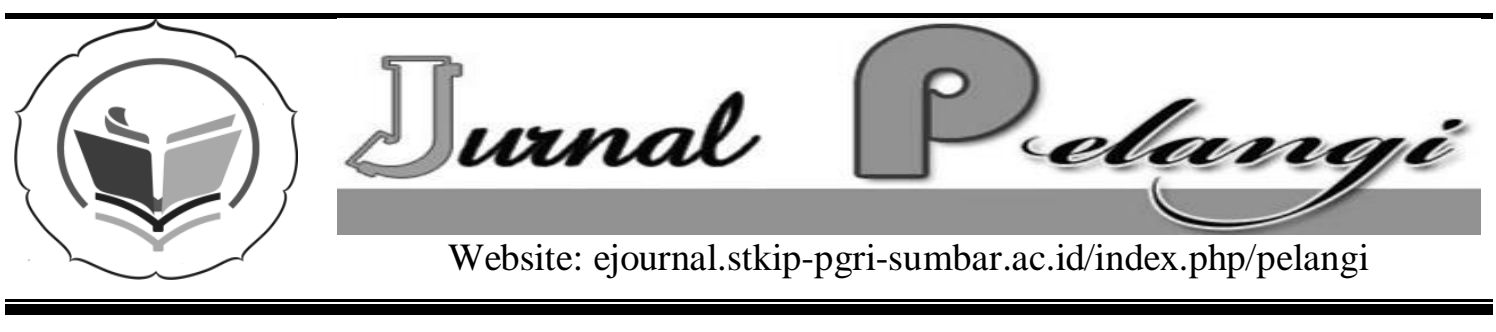

\title{
KETERCAPAIAN TUGAS PERKEMBANGAN REMAJA DAN FAKTOR PENYEBAB TERJADINYA MERANTAU PADA MASYARAKAT MINANG
}

\author{
Fuaddillah Putra
}

STKIP PGRI Sumatera Barat

putraalyanifahmi@gmail.com

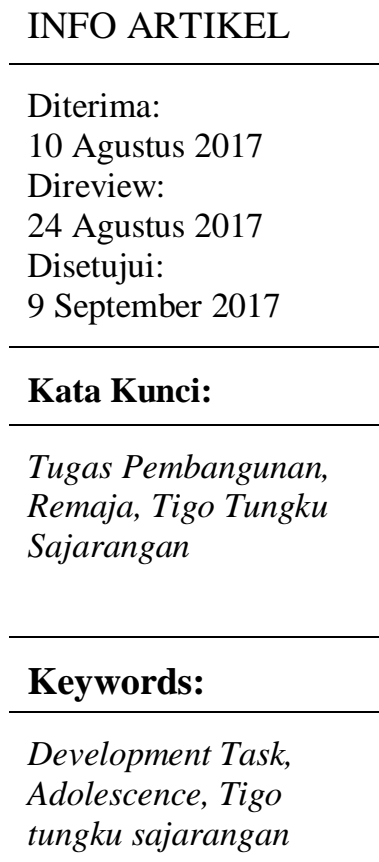

\begin{abstract}
Abstrak
Minangkabau adalah salah satu budaya yang ditemukan di Indonesia dan termasuk budaya yang memiliki banyak anggota bila dibandingkan dengan budaya lain. Salah satu karakteristik budaya minangkabau adalah kebiasaan orangorang yang pergi dari rumah untuk mencari nafkah ke negara atau daerah lain dalam waktu yang sangat lama, kebiasaan ini dikenal dengan sebutan "Merantau". Dalam pelaksanaan para migran ini, persiapannya dimulai dari remaja di mana keluarga jangka panjang akan memberikan informasi tentang pekerjaan di luar negeri dan apa persyaratan pekerjaan tersebut.

Abstract
Minangkabau is one of the cultures found in Indonesia and
includes a culture that has many members when compared
with other cultures. One characteristic of minangkabau culture
is the habit of the people who go from home to earn a living to
the country or other areas in a very long time, this habit is
known as "Merantau". In the execution of these migrants, the
preparation has begun from teenagers where long-term
families will provide information about overseas jobs and what
are the requirements of the job.
\end{abstract}

\section{PENDAHULUAN}

Tugas perkembangan adalah salah satu bentuk manifestasi dari tugas-tugas yang harus dan dapat dipenuhi oleh banyak orang yang menjalani hidup, hal ini dikarenakan dengan terpenuhinya tugas tersebut akan membantu dan mengajarkan setiap individu agar terus dan dapat bertahan dalam menjalani hidup.

Hurlock dalam (Fuaddillah Putra, 2012: 34) menjelaskan bahwa tugastugas perkembangan adalah kemampuan atau keterampilan yang harus dikuasi oleh seorang individu pada periode 
tertentu, yang mana dari pengusaan kemampuan atau keterampilan yang telah dilakukan oleh individu akan berdampak positif terhadap perkembangan yang akan dijalani pada periode selanjutnya. Havighurst (dalam Ausubel, 2002: 52) menjelaskan beberapa tugas-tugas perkembangan yang harus dipenuhi oleh seorang individu pada remaja, tugas perkembangan tersebut diantaranya adalah:

1. Accepting one's physique and accepting a masculine or feminine role;

2. Developing new relations with age mates of both sexes;

3. Establishing emotional independence of parents and other adults;

4. Achieving assurance of economic independence;

5. Selecting and preparing for an occupation;

6. Developing intellectual skills and concepts necessary for civic competence; (

7. Desiring and achieving socially responsible behavior;

8. Preparing for marriage and family life;

9. Building conscious values in harmony with an adequate scientific world picture;

Dari kesembilan tugas

perkembangan itu, terdapat salah satu tugas perkembangan yang meminta seorang individu khususnya remaja untuk mampu mengenal, memahami dan mempersiapakan diri menghadapi pekerjaan. Artinya disini adalah seorang remaja harus mengetahui spesifikasi dari salah satu pekerjaan yang ia inginkan dan gemari, baik itu dari syarat memasuki pekerjaan, dan kompetensi yang harus dimiliki dan sebagainya. situasi mengenali karakteristik suatu pekerjaan ini juga dapat termasuk proses pendidikan dalam menacapai suatu pekerjaan atau karier yang ingin ditempuh.

Mempersiapkan karier merupakan salah satu tugas-tugas perkembangan yang harus dipenuhi oleh remaja, hal ini dikarenakan pada masa remaja yang sedang dijalani, merupakan salah satu tahapan untuk mengenal segala aspek yang berhubungan dengan pengenalan karir atau pekerjaan yang akan mereka jalani kelak hal ini lebih dikenal dengan aspirasi karier atau harapan seorang remaja terhadap keberhasilannya di masa yang akan datang, Pusat Bahasa Diknas (dalam Afriyadi, 2013: 94).

Super (dalam Sharf, 1992: 157) menjelaskan bahwa salah satu aspirasi karier seseorang merupakan salah satu proses kematangan karier individu, maka dengan itu perencanaan karier mulai dari sekarang merupakan salah satu tahap yang membantu remaja dalam menentukan karier mereka kelak atau yang bisa dikatakan dengan cita-cita. Rojewski (dalam Paton, dkk. 2005: 132) menjelaskan bahwa cita-cita seseorang yang berhubungan dengan karier merupakan salah satu faktor yang dapat memotivasi seseorang dalam meningkatkan kompetensi yang mereka miliki, sehingga mereka akan selalu berusaha.

Herr (2004: 398) menyatakan bahwa banyak faktor-faktor yang dapat mempengaruhi persiapan karier seseorang di antaranya: orang tua, gaya dan kasih orang tua, gengsi atau prestise, peran gender dan ras, serta kondisi fisik. Pandia (2007: 33) menjelaskan bahwa pada masa remaja ini seorang remaja akan menjalankan sebuah proses yang dikenal dengan masa orientasi karier dan aspirasi karier, mereka akan berusaha memahami aspirasi karier mereka dan mengenali karier yang mereka inginkan kelak, sehingga setelah proses mengenali mereka akan berusaha untuk memenuhi 
persyaratannya, seperti contoh: syarat menjadi seorang anggota kepolisian adalah memiliki tubuh yang sehat dan setelah mereka mengetahui itu mereka akan berusaha menjaga kondisi tubuh dan kebugarannya agar dapat lulus untuk menjadi seorang polisi.Dari penjelasan di atas, dapat disimpulkan bahwa tugas perkembangan merupakan salah satu bentuk dari kewajiban yang harus mampu dijalani dan dipahami oleh individu ketika menajalani kehidupan dan bersosialisasi dengan lingkungannya. Kemudian dalam tugas perkembangan ini, pekerjaan merupakan salah satu bentuk dari kewajiban yang harus mampu dicari dan dijalani sesuai dengan kompetensi dan karakteristik yang dimiliki, salah satu contohnya adalah pelaksanaan kegiatan rantau yang dilakukan oleh pemuda atau remaja di minang Kabau ketika sudah memiliki bekal dalam menjalani kehidupan.

Rantau atau kegiatan merantau merupakan salah satu kegiatan meninggalkan tanah leluhur dan melanjutkan "manyambuang hiduik" di nagari orang lain, dengan maksud menacri tempat tinggal, pekerjaan bahkan pasangan hidup. Bhagas Adhindaru Wibisono (2012:2) menjelaskan bahwa pembangunan Indonesia yang tidak merata dan lebih terpusat di kota-kota besar, terutama di pulau Jawa, sehingga banyak orang Indonesia merantau untuk mencari pekerjaan atau pendidikan yang lebih baik. Bagi orang Minang atau sering disamakan sebagai orang Padang hampir separuh jumlah keseluruhan anggota masyarakat ini berada dalam perantauan. Situasi ini membuat dan memberikan stimulus kepada para remaja yang berada di kampung untuk memiliki keinginan agar dapat mencicipi seperti apa rasa perantauan dan hidup di negeri orang. Merantau merupakan proses interaksi masyarakat Minangkabau dengan dunia luar, Bagi sebagian besar masyarakat Minangkabau, merantau merupakan sebuah cara yang ideal untuk mencapai kematangan dan kesuksesan. Situasi yang telah dijelaskan sebelumnya merupakan salah satu penyebab terjadinya kegiatan rantau yang dilakukan oleh orang-orang minang, yang bertujuan mencari penghidupan bahkan pasangan di negri orang.

Bhagas Adhindaru Wibisono (2012:3) etos merantau orang Minangkabau sangatlah tinggi, bahkan diperkirakan tertinggi di Indonesia, dari hasil studi yang pernah dilakukan oleh Mochtar Naim (dalam Adhindaru Wibisono, 2012:3) pada tahun 1961 terdapat sekitar $32 \%$ orang Minang yang berdomisili di luar Sumatra Barat. Kemudian pada tahun 1971 jumlah itu meningkat menjadi $44 \%$. Berdasarkan sensus tahun 2010, etnis Minang yang tinggal di Sumatra Barat berjumlah 4,2 juta jiwa, dengan perkiraan hampir separuh orang Minang berada di perantauan, para perantau Minang, hampir keseluruhannya berada di kotakota besar Indonesia dan Malaysia.

Bhagas Adhindaru Wibisono (2012:4) menjelaskan bahwa ada beberapa faktor yang melatar belakangi orang Minang memilih untuk merantau : (1). Faktor Ekonomi, berkurangnya lahan pertanian yang menjadi mata pencaharian pokok keluarga dengan tumbuhnya lahan baru untuk perkebunan dan pertambangan. (2). Faktor Ekologi dan Geografis, Minangkabau adalah daerah yang terpencil di luar pusat perdagangan dan politik, sehingga orang luar daerah enggan mendatangi Minangkabau. (3). Faktor Budaya, penyebabnya ialah sistem kekerabatan matrilineal. Dengan sistem ini, penguasaan harta pusaka dipegang oleh kaum perempuan sedangkan hak kaum pria dalam hal ini cukup kecil. Selain itu, setelah masa akil baligh para pemuda 
tidak lagi dapat tidur di rumah orang tuanya, karena rumah hanya diperuntukkan untuk kaum perempuan dan anak-anak. (4) . Faktor Pendidikan, setiap pelajar yang pergi merantau membukakan jalan bagi pelajar berikutnya untuk melakukan hal yang sama. Berdasarkan hasl wawancara dengan beberapa orang tua yang pernah merantau, terungkap bahwa proses kegiatan merantau yang pernah dilakukan dikarenakan oleh adanya ajakan dan iming-iming dari keluarga yang sedang merantau, kurangnya lapangan pekerjaan dan adanya kebosanan terhadap lingkungan dan interaksi sosial yang itu ke itu saja, kurangnya pertimbangan dan persiapan dari para calon perantau yang akan mencari pekerjaan diluar nagari Minang Kabau, hal ini seperti tidak adanya pengasahan keterampilan yang dapat digunakan dan sebagainya. dari penejlasan di atas dapat terlihat bagaimana adanya kaitan antara kemampuan dalam memenuhi tugas perkembangan khususnya mampu memilih dan mempersiapkan pekerjaan dengan kegiatan perantauan yang terdapat di Mianag Kabau.

Tujuan dari peneitian ini adalah untuk mengungkapkan faktor-faktor penyebab terjadinya kegiatan merantau di daerah Minang Kabau khususnya daerah kampung Jambak Kelurahan Batipuh Panjang Kecamatan Koto Tangah Kota Padang, ditinjau dari :

1. Terjadinya proses perantauan yang ditinjau dari aspek ekonomi, berkurangnya lahan pertanian yang menjadi mata pencaharian pokok keluarga dengan tumbuhnya lahan baru untuk perkebunan dan pertambangan.

2. Terjadinya proses perantauan yang ditinjau dari aspek ekologi dan Geografis, Minangkabau adalah daerah yang terpencil di luar pusat perdagangan dan politik, sehingga orang luar daerah enggan mendatangi Minangkabau.

3. Terjadinya proses perantauan yang ditinjau dari aspek budaya, penyebabnya ialah sistem kekerabatan matrilineal. Dengan sistem ini, penguasaan harta pusaka dipegang oleh kaum perempuan sedangkan hak kaum pria dalam hal ini cukup kecil. Selain itu, setelah masa akil baligh para pemuda tidak lagi dapat tidur di rumah orang tuanya, karena rumah hanya diperuntukkan untuk kaum perempuan dan anak-anak.

4. Terjadinya proses perantauan yang ditinjau dari aspek pendidikan, setiap pelajar yang pergi merantau membukakan jalan bagi pelajar berikutnya untuk melakukan hal yang sama

5. Ketercapaian Tugas-tugas Perkembangan "Memilih dan Mempersiapkan Pekerjaan”.

\section{METODE PENELITIAN}

Penelitian yang dilakukan termasuk penelitian kualitatif yang menghasilkan data deskriptif. Menurut Moleong (2005:6) penelitian kualitatif adalah penelitian yang bermaksud untuk memahami fenomena tentang apa yang dialami oleh subjek penelitian misalnya perilaku, persepsi, motivasi, tindakan, dll. Moleong (2005:6) dalam penelitian kualitatif masalah dipandang secara holistik, pada suatu konteks khusus yang alamiah dan dengan memanfaatkan berbagai metode ilmiah. Teknik pengambilan sampel dalam penelitian ini adalah snowball sampling, dan subjek dalam penelitian ini adalah orang-orang yang pernah melakukan perantauan dan telah kembali ke tanah leluhurnya "Minang Kabau". Pengambilan data yang dilakukan penelitia adalah dengan cara wawancara dan observasi. 
Keabsahan data dan kepercayaan data penelitian, peneliti lakukan dengan beberapa cara, yaitu:

1. Kepercayaan (Credibility)

2. Keteralihan (Transferability)

3. Dapat dipercaya (Dependability). Sugiyono (2011: 366-377).

Teknik analisis data yang digunakan adalah triangulasi data yaitu:

\section{Reduksi Data (Data Reduction)}

Reduksi data merupakan proses merangkum, memilih hal-hal yang pokok, memfokuskan pada hal-hal yang penting, dicari tema dan polanya dan membuang yang tidak perlu dari data yang diperoleh di lapangan

2. Penyajian Data (Display Data)

Penyajian data dapat dilakukan dalam bentuk uraian singkat, bagan hubungan antar kategori atau dalam bentuk teks yang bersifat naratif dengan menyajikan data dapat mempermudah dalam memahami apa yang terjadi, merencanakan apa yang akan dilakukan selanjutnya berdasarkan apa yang telah dipahami

3. Penarikan Kesimpulan (Verifikasi)

Penarikan kesimpulan merupakan analisis lanjutan dari reduksi data dan penyajian data sehingga data dapat disimpulkan dalam bentuk deskriptif, Sugiyono (2011: 366-377).

\section{HASIL DAN PEMBAHASAN}

Berdasarkan hasil analisis data yang menggunakan teknik triangulasi data, terungkap bahwa:

Faktor Ekonomi, berkurangnya lahan pertanian yang menjadi mata pencaharian pokok keluarga dengan tumbuhnya lahan baru untuk perkebunan dan pertambangan

Perantauan yang dilakukan oleh remaja atau pemuda dan pemudi di MInang Kabau dikarenakan adanya pengurangan lahan pertanian yang dikarenakan pemekaran daerah dan pembangunan, yang mengakibatkan semakin berkurangnya lahan pertanian. Daerah minangkabau mayoritas dari beberapa daerah adalah memiliki pekerjaan sebagai petani, dimana pertanian padi, getah dan sawit merupakan salah satu andalan bagi masyarakat agar dapat menghasilkan uang yang dapat meningkatkan status dari keluaraga. Oleh karena itu, jika lahan pertanian mulai berkurang akan dapat berdampak pada pengurangangan tempat bekerja yang akan berkorelasi dengan munculnya niat masyarakat untuk pergi mencari nafkah penghidupan kedaerah-daerah lain, ini lah yang dikenal dengan kegiatan merantau.

Faktor Ekologi dan Geografis, Minangkabau adalah daerah yang terpencil di luar pusat perdagangan dan politik, sehingga orang luar daerah enggan mendatangi Minangkabau.

Jika di dipandang dari sudut ekologi dan geografis, kegiatan perantauan yang dilakukan oleh masyarakat yang berada di daerah selain kota Padang, dapat menjadi pemicu timbulnya kegiatan merantau ini. Hal ini dikarenakan adanya salah satu karakteristik dari remaja yaitu memiliki rasa ingin tahu dan proses pencarian jati diri yang mengakibatkan mereka memiliki rasa ingin tahu terhadap situasi dunia luar yang berkembang maka dapat menjadi salahsatu penyebab timbulnya perantauan

\section{Faktor Budaya}

penyebabnya ialah sistem kekerabatan matrilineal. Dengan sistem ini, penguasaan harta pusaka dipegang oleh kaum perempuan sedangkan hak kaum pria dalam hal ini cukup kecil. Selain itu, setelah masa akil baligh para pemuda tidak lagi dapat tidur di rumah orang tuanya, karena rumah hanya 
diperuntukkan untuk kaum perempuan dan anak-anak.

Selanjutnya dilihat dari faktor budaya atau kebiasan, perantauan yang dilakukan oleh masyarakat minang kabau dapat dikarenakan adanya kebiasan dari orang yang terdahulu yang pernah merantau, dan mengakibatkan munculnya keinginan merantau tumbuh dalam diri pemuda dan pemudi masayarakat minang kabau. Seperti contoh, di kota Padang daerah Kampung Jambak, hampir $70 \%$ dari pemuda dan pemudi nya melakukan perantauan, dimana mereka merantau ini diakibatkan cerita-cerita dari orangtuanya maupun sanak saudara yang mengajak mereka untuk merantau.

Faktor Pendidikan, setiap pelajar yang pergi merantau membukakan jalan bagi pelajar berikutnya untuk melakukan hal yang sama

Berdasarkan analisis data yang telah dilakukan, faktor pendidikan tidak begitu kuat memiliki pengaruh terhadap perantauan yang dilakukan oleh masyarakat minangkabau. Hal ini dikarenakan orang atau pemuda dan pemudi minangkabau melakukan merantau ini dikarenakan niat mereka hanya untuk mencari nafkah, bukan melanjutkan jenjang pendidikan. Namun itu tidak berlaku bagi semua pemuda dan pemudi yang merantau, karena jika dipersentasekan ada $6 \%$ dari total masyarakat yang merantau, diarenakan ingin melanjutkan pendidikan di tempat perantauannya.

Ketercapaian Tugas-tugas Perkembangan "Memilih dan Mempersiapkan Pekerjaan",

Selanjutnya jika dilihat dari ketercapaian tugas perkembangan dalam hal memilih dan mempersiapkan pekerjaan, masyarakat minangkabau berada pada kategori baik, hal ini dikarenakan adanya pengenalan tentang pekerjaan dari lingkungan tempat tinggal, khususnya dari para perantau yang telah pernah melakukan kegiatan merantau. Namun jika dilihat dari situasi dan pekerjaan yang dikenalkan belum berada pada kategori baik, karena pekerjaan yang didapatkan mereka adalah pekerjaan yang belum memiliki organisasi atau dapat dikatakan sebagai pekerjaan yang belum tetap.

\section{PENUTUP}

Berdasarkan penjelasan di atas, dapat disimpulkan bahwa kegiatan merantau yang dilakukan oleh masyarakat minangkabau, disebabkan oleh empat hal, diantaranya

1. Faktor Ekonomi, berkurangnya lahan pertanian yang menjadi mata pencaharian pokok keluarga dengan tumbuhnya lahan baru untuk perkebunan dan pertambangan memiliki pengaruh yang cukup besar.

2. Faktor Ekologi dan Geografis, Minangkabau adalah daerah yang terpencil di luar pusat perdagangan dan politik, sehingga orang luar daerah enggan mendatangi Minangkabau memiliki pengaruh yang cukup besar.

3. Faktor Budaya, penyebabnya ialah sistem kekerabatan matrilineal. Dengan sistem ini, penguasaan harta pusaka dipegang oleh kaum perempuan sedangkan hak kaum pria dalam hal ini cukup kecil. Selain itu, setelah masa akil baligh para pemuda tidak lagi dapat tidur di rumah orang tuanya, karena rumah hanya diperuntukkan untuk kaum perempuan dan anak-anak memiliki pengaruh yang cukup besar.

4. Faktor Pendidikan, setiap pelajar yang pergi merantau membukakan jalan bagi pelajar berikutnya untuk melakukan hal yang sama tidak 
memiliki pengaruh yang cukup besar.

5. Selanjutnya jika dilihat secara umum, ketercapaian tugas perkembangan masyarakat minangkabau dalam hal memilih dan mempersiapkan diri dalam mneghadapi memasuki dunia kerja berada pada kategori baik.

\section{UCAPAN TERIMA KASIH}

Terbitnya tulisan ini tidak terlepas dari bantuan berbagai pihak, untuk itu penulis ucapkan terima kasih kepada UP3M STKIP PGRI Sumatera Barat dan pengelola jurnal Pelangi yang telah memberikan saran dan revisi dalam penulisan artikel ini.

\section{DAFTAR PUSTAKA}

Afriyadi. 2013. Tingkat Aspirasi Karir Siswa Ditinjau dari Jenis Kelamin, Jurusan dan Daerah Tempat Tinggal. Tesis. Tidak Diterbitkan. Pendidikan Pasca Sarjana Bimbingan dan Konseling Universitas Negeri Padang

Ausubel, D. P. 2002. Theory and Problems of Adolescent Development ( $3 \mathrm{rd}$. ed). Lincoln: Universe.

Bhagas Adhindaru Wibisono. 2012. Modal Sosial kelompok Pedagang Asal Minang di Kota Surakarta. Dialektika. 2-18
Fuaddillah Putra. 2012. Ketercapaian tugas-tugas perkembangan siswa SMA dan Pondok Pesantren. Tesis. Tidak Diterbitkan. Pendidikan Pasca Sarjana Bimbingan dan Konseling Universitas Negeri Padang

Herr, Edwin L. 2004. Career Guidance and Counseling Through the Lifespan: Systematic Approaches (Sixt Edition). USA: Merrill.

Pandia, Weny Savitry S, 2007. Status Identitas Ego, Orientasi Karier, Dan Aspirasi Karier Remaja Perempuan, Universitas Katolik Atma Jaya. Jurnal. Jurnal Psikologi. Vol. 20; No. 2.

Patton, Wendy Creed, Peter. 2005. Occupational Aspiration and Expectation of Australian Adolescent. Australian Journal of Career Development. (Online) (http://www.freepatentsonline.com /article/Australian-journalcareer development/167103472, diakses Oktober 2010).

Sharf, R. 1992. Aplying Career Development Theory to Counseling. California: Books/Cole Publishing Company

Sugiyono. 2011. Metode Penelitian Pendidikan. Bandung: Alfabeta 